Yuri Tsivian

\title{
Joan Neuberger's This Thing of Darkness
}

Yuri Tsivian

William Colvin

Professor Emeritus,

Department of Cinema and Media Studies,

University of Chicago

(Chicago, USA)
"Excellent, one of a kind, unparalleled in scope and depth, lives up to its subject (Eisenstein's film, not that thing of darkness)" - we all know this, but is this all that there is to it? Great books happen, as do great films - rarely, but they do. So, I thought, what can I add to this round table - other than yet another superlative, a large pile of which would be already on the table by the time it is my turn to speak?

So I asked myself, what's unique about Joan Neuberger's work - what makes it a book that no one else, not even me, could have possibly written? If I were a librarian, how would I shelve and categorize Neuberger's new book and what database would I use to allow our students to more easily find it?

No such shelf or cage, and no such database exists. What we are looking at, dear children, is a very strange animal, a mutant. Here is a book on an old historical biopic written by a professional historian. And yet I do not intend to reduce Neuberger's image to that of a historian. Open This Thing of Darkness on any page, and you will instantly recognize in its author a film scholar acute to lighting and sighting, to music and landscapes, and other joys of immersion into your mother's womb, "this thing of darkness".

There is nothing un-catalogable about a book on film written by a historian. Historians do occasionally write on 
cinema, and we occasionally read their writings, and very often find them useful but not quite in the sense Neuberger's masterpiece is useful for film studies, or, for that matter, the study of history as such ${ }^{1}$.

One of such film-minded historians was Richard Stites in the US and remains Boris Kolonitsky in St. Petersburg - both approach films as ideological artefacts of the past insightfully, cleverly, if, in the case of Stites, not without a Zeit-Geistish flavor to his approach ${ }^{2}$. Another way of approaching cinema from the historical viewpoint is that of Rashid Yangirov - a historian more curious about filmmakers than their films, in people more than texts, names and documents more than titles and visuals. Yangirov was a true metadata historian to whom we owe a breathtaking panorama of a forgotten community of half-forgotten émigré filmmakers and critics ${ }^{3}$.

Neuberger's history is different. Instead of assuming a bird's eye point of view on the Soviet film-land, she nose-dove into it like a kid-loving pelican, picked one film and brought it to us in a big beak of a book. That is not to portray Joan Neuberger as a shape-shifter, a historian-turned-film-scholar. Yes, film scholars do write booklength studies on a single movie while political historians rarely do, but the choice of this specific format does not turn Neuberger into a film scholar. There is a lot of superb film scholarship to be found here, but the stunt that makes Neuberger's scholarship unique is that, for all its film-scholarship lenses it remains a historical study par excellence.

That I call it a stunt is for the following reason. We know of serious historical studies into the rule of Ivan the Terrible, and are familiar with many historical studies of Stalinism; and it is not hard to imagine a historian who would be an expert in these different and yet uncannily similar epochs. But that these two epoch would loom so large and clear, in all their shining darkness, in many mutual projections - filmic projections, political projections, punitive incarnations, sinister clownishness - under the same book cover, is an intellectual feat worthy of Eisenstein's own.

The scholarly wisdom of Neuberger's book is that it refuses to comply with the time-honored distinction, according to which history studies lives and according to which art history (which includes film history) studies artworks. According to this distinction, the history proper studies processes while art history studies results novels, pictures or films. Here, Neuberger treats Eisenstein's movie in its becoming, in its making, as a process - much as a historian would a society or a biographer the life of a human being.

We, who do film history, tend to dismiss screenplays, sketches and storyboards as a disposable scaffolding used to construct the masterpiece we value so. Neuberger treats all preliminary materials as a rich dynamic world, of which the finished film is only a part. Here is a historian for you - nay, the historian. And, as a genuine historian, Neuberger refuses to judge - that is, to succumb to the petit-bourgeois political temptations of the moment. Was Eisenstein a Stalinist? Or was he a dissident before the date?

When we say Eisenstein should or should not have said or done this or that, we do it from the safety of hindsight, and because we assume that the fact of living today somehow entitles us to judge the past. Judging is fine - unless you are a historian, 
for in this case judgement blocks the understanding of the past - the only thing the historian is able to enrich us with.

"It is not my intention to whitewash him or to turn Ivan the Terrible into Ivan the Sweet", Neuberger quotes an entry from Eisenstein's working journal. "The fundamental aim of the film was to show Ivan in the whole range of his activity and the struggle for the state of Muscovy. And it should be said straight away that this activity and this struggle were colossal and bloody. But I do not intend to wipe one drop of blood from the life of Ivan the Terrible. Not to whitewash, but to explain" (37).

Neuberger's position vis-à-vis Eisenstein is like Eisenstein's vis-à-vis Ivan. "I am bringing up a few of these temperamental contradictions to emphasize that the goal in analyzing both Eisenstein and Ivan is not to judge whether they were good or evil, or even good and evil, but to understand something about how they behaved in specific conditions, how those conditions combined with experience and temperament to produce their behaviors, and to understand what they thought they could and should do" (21).

In this, Joan Neuberger is Joan the Historian.

1 James Goodwin, Eisenstein, Cinema, and History (Urbana, 1993).

2 See the section on the cinema of the 1930's in: Stites R. Russian Popular Culture: Entertainment and Society since 1900 (New York, 1992); Kolonitsky B. "Introductory Lecture to Dziga Vertov's 1918 Anniversary of the Revolution", (unpublished ms., 2019); see also "The premiere of the grandiose 'Anniversary of the Revolution' by Vertov took place in St. Petersburg”, Krasnaia vesna, 12 September 2019. Available at: https://rossaprimavera.ru/news/37432169 (accessed: 10.06.2020).

3 Yangirov R.M. Chronicle of the cinematic life of the Russian diaspora abroad, ed. by Z.M.Zevina, 2 vols (Moscow, 2010).

\title{
FOR CITATION
}

Tsivian Yu. 'Joan Neuberger's This Thing of Darkness', Modern History of Russia, vol. 11, no. 1, 2021, pp. 248-251. https://doi.org/10.21638/11701/spbu24.2021.119 UDC 930

\begin{abstract}
The note is about the place of Joan Neuberger's monograph among books on Eisenstein's Ivan the Terrible, and, more broadly, among writings on period films, be they by film historians or by historians proper. The book is a triple portrayal — of Eisenstein, his Ivan, and, indirectly, of Stalin, whose favorite pastime was to use historical novels, plays, and films on Russia's historic tyrants as one might a vanity mirror. The virtue of Neuberger's approach is that, rather than judge or define, she successfully captures the ambiguity of each of her three protagonists. It is as much an analysis of the movie as an ambivalent mirror as it is of the person that holds it and of the one who expects to see in it a flattering reflection of himself - to no avail. Instead of assuming a bird's eye point of view on the Soviet film-land, Neuberger nose-dove into it like a kid-loving pelican, picked one film and brought it to us in a big beak of a book. That is not to portray Joan Neuberger as a shape-shifter, a historian-turned-film-scholar. Yes, film scholars do write book-length studies on a single movie while political historians rarely do, but the choice of this specific format does not turn Neuberger into a film scholar. There is a lot of superb film scholarship to be found here, but the stunt that makes Neuberger's scholarship unique is that, for all its film-scholarship lenses, it remains a historical study par excellence.
\end{abstract}

Keywords: film, cinema, ambiguity, Eisenstein, Ivan the Terrible, Stalin.

Author: Tsivian Yu. - William Colvin Professor Emeritus, University of Chicago (Chicago, USA); ytsivian@uchicago.edu 
University of Chicago, 5801, South Ellis Avenue, Chicago, Illinois, 60637, USA

References:

Goodwin J. Eisenstein, Cinema, and History (Urbana, 1993).

Stites R. Russian Popular Culture: Entertainment and Society since 1900 (New York, 1992).

Yangirov R. M. Chronicle of the cinematic life of the Russian diaspora abroad, ed. by Z. M.Zevina, 2 vols. (Moscow, 2010).

Received: June 18, 2020

Accepted: October 27, 2020 